\title{
Electrical and Neurochemical Conduction through Sciatic Nerve at Low Temperature
}

\author{
Hafedh Abdel Melek*, Amel Hanini, Azzouz Amina and Mohsen Sakly \\ Laboratoire de Physiologie Intégrée, Carthage University, Tunisia
}

Submission: March 27, 2017; Published: June 05, 2017

*Corresponding author: Hafedh Abdel Melek, Faculté des Sciences de Bizerte 7021 Jarzouna, Laboratoire de Physiologie Intégrée, Carthage University, Tunisia, Fax: (216)-72-590-566; Email: Hafedh.Abdelmelek@fsb.rnu.tn

Abstract

Physiological studies have during cold acclimation could be associated to electrical and /or neurochemical changes with adaptation leading to non-shivering thermogenesis. Besides the action of glucagon, catecholamines or superconductor behavior could play a role in the stimulation of thermogenesis. We have described a procedure for evaluating superconductor-like behaviour in frog and differences in the concentration of monoamines in duckling sciatic nerve at different temperature acclimation in order to report an innovative study model of species adaptation to cold.

Keywords: Superconductor; Monoamines; Sciatic nerve; Cold

\section{Introduction}

Several studies of the nervous system dealing with electrical conductivity have shown the existence of superconductor-like behaviour in sciatic nerves of poikilotherm and endotherm [1,2]. Interestingly, Abdelmelek et al. [1] demonstrated that evolution from poikilotherm (frog) to endotherm (rabbit) lead to a grade shift in relative "superconducting" transition temperature (Tc) at $240 \mathrm{~K}$ and $300 \mathrm{~K}$ respectively, thus showing an adaptive mechanism involving electrical conductivity "superconductorlike behavior" in sciatic nerves. The superconductor-like behaviour in sciatic nerves can be regarded as a characteristic of species [1,2]. Superconductivity is the ability of certain materials to conduct electric current with zero resistance. The name given to the phenomenon was due to the very high electrical conductivity below the critical temperature. It might therefore be expected that natural selection on nerve or neuron conduction could have caused several structural changes [1-3]. The conduction velocity is dependent on the axonal diameter, the presence of myelin and the properties of the membrane $[1,2]$. Electrical activity is of major importance in the function of nerve cells, playing a fundamental role in the transmission of signals and in the processing of information in the nervous system. Recent data showed a modulation effect of temperature $(279 \mathrm{~K})$ on the sciatic nerve or spinal cord monoaminergic system in ducklings [1,2]. Thus, natural selection on nerve or neurone (chemical and electrical) conduction could have caused several structural changes.

Electrical properties of frog sciatic nerve at low temperature

Our studies point to the existence of a striking decrease of nerve resistivity at about $240 \mathrm{~K}$ in frog sciatic nerves, showing a superconductor-like behaviour. When the electrical contacts were embedded into the nerve, a linear decrease of the sciatic nerve resistivity is observed at $240 \mathrm{~K}<\mathrm{T}<300 \mathrm{~K}$ in frog and a rise of electrical conductivity is apparent below $234 \mathrm{~K}$ respectively. This dependence is generally associated with a metallic behaviour. Then, once the sciatic nerve temperature is driven below $234 \mathrm{~K}$ in frog, the resistivity decreases abruptly and then it remains constant. Electrical evolution below $234 \mathrm{~K}$ can be regarded as a superconductor-like behavior. Recent results have demonstrated the existence of superconductor-behavior in nerve or DNA [1-5]. Understanding these complex functions requires a multidisciplinary approach. The present study on the sciatic nerve revealed a temperature dependency of the electric resistivity. According to our findings, the marked decrease of resistivity at low ambient temperature can be mediated by a mechanism, which has many similarities with inorganic and organic superconductors $[1,2,4]$. Thus, the decrease or increase of temperature has a proportional effect on the sciatic nerve 
resistivity and could be used as a test of integrity of nervous system during freezing process. By contrast, difference between endotherm (rabbit, Tconset: $300 \mathrm{~K}$ ) and poi kilotherm (frog, Tconset: $250 \mathrm{~K}$ ) could be explained by fundamental anatomical and functional nerves properties related to the development of metabolic function and the development of myelin [1]. Nerve fibres conduct nerve impulses very quickly because the myelin sheath has gaps, which allows the nerve impulse to jump from gap to gap and travel faster [1]. The temperature transition (Tconset) in the sciatic nerves of frog remains constant and reproducible. If we assume the existence of "superconductivity" behavior in nerves, there is an increasing evidence to attribute this superconductivity to myelin sheaths.

\section{Duckling sciatic nerve monoaminergic system response to cold acclimatization}

Physiological studies have shown that changes in circulating catecholamines levels during cold acclimation could be associated with adaptive changes leading to nonshivering thermogenesis (NST) [6,7]. Besides the action of glucagon, catecholamines play a role in the stimulation of avian thermogenesis $[8,9]$. Previous study from our group suggests the presence of adaptive mechanisms involving the spinal cord dopaminergic and serotonergic pathways after chronic exposure to cold. The present study demonstrates that chronic cold exposure stimulates the noradrenergic activity in the duckling sciatic nerve. By contrast, cold exposure failed to alter the dopaminergic and serotonergic activities. Our data show that NE, DA, 5-HT, DOPAC (3, 4-dihydroxyphenylacetic acid) and 5-HIAA (5-hydroxyindolacetic acid) can be readily detected in sciatic nerve extracts of 6 week-old ducklings. The data show a similar distribution of monoamines and their metabolites in the right and left sciatic nerves. 5-HT and DA and their metabolites remained unchanged following cold exposure. We have described a procedure for evaluating superconductor-like behaviour in frog and differences in the concentration of monoamines in duckling sciatic nerve at different temperature acclimation.

\section{References}

1. Abdelmelek H, Cottet-Emard JM, Pequignot JM, Et Barré H (2000) Changes with age in spinal cord monoaminergic system responses to cold acclimatization. J Neural Transm 107: 1175-1185.

2. Abdelmelek H, M'Chirgui A, Ben Salem M, Sakly M (2003) Impact of evolution on the electrical properties of sciatic nerves : Superconductivity-like. Physical \& Chemical News 13: 132-134.

3. Mbainaibeye J, E Ben Braik, M Ben Salem, M Sakly, H Abdelmelek (2012) Analysis and Characterization of the Electrical Conductivity Behavior of the Sciatic Nerve using Wavelet Transform and Signal Processing. International Journal of Electronics Communication and Computer Engineering. 3(4): 953-960.

4. Kasumov AY, Kociak M, Guéron S, Revlet B, Volkov VT, et al. (2001) Proximity-induced superconductivity in DNA. Science 291(5502): 280-282.

5. Abdelmelek H, El-May Ben Hamouda A, Ben Salem M, Pequignot JM, Sakly M (2003) Electrical conduction through nerve and DNA. Chinese Journal of Physiology 46(3): 1-8.

6. Abdelmelek H, Cottet-Emard JM, Pequignot JM, Barré H (2003) Sciatic nerve monoaminergic system responses to cold acclimatization in Muscovy duckling. J Neural Transm 110(12): 1359-1367.

7. Filali-Zegzouti Y, Abdelmelek H, Rouanet JL, Cottet-Emard JM, Pequignot JM, et al. (2000) Involvement of the catecholaminergic system in glucagon-induced thermogenesis in Muscovy ducklings (Cairina moschata). Pflugers Arch 441(2-3): 275-280.

8. Eldershaw T, Duchamp C, Ye JM, Clark MG, Colquhoun EQ (1997) Potential for nonshivering thermogenesis in perfused chicken (Gallus domesticus) muscle. Comp Biochem Physiol 117A: 5545-554.

9. Marmonier F, Duchamp C, Eldershaw T, Cohen-Adad F, Barré H (1997) Hormonal control of thermogenesis in perfused muscle of Muscovy ducklings. Am J Physiol 273(5 Pt 2): R1638-R1648.

This work is licensed under Creative

Commons Attribution 4.0 Licens

DOI: 10.19080/OAJNN.2017.04.555630
Your next submission with Juniper Publishers

$$
\text { will reach you the below assets }
$$

- Quality Editorial service

- Swift Peer Review

- Reprints availability

- E-prints Service

- Manuscript Podcast for convenient understanding

- Global attainment for your research

- Manuscript accessibility in different formats

( Pdf, E-pub, Full Text, Audio)

- Unceasing customer service

Track the below URL for one-step submission

https://juniperpublishers.com/online-submission.php 